\title{
Nursing Students' Perceptions on The Management of Nursing Laboratory
}

\author{
Sari Ali Astuti, Wida Sulastri, Atlastieka Praptiwi \\ Faculty of Nursing Universitas Padjadjaran \\ Email: sari.astuti@unpad.ac.id
}

\begin{abstract}
The nursing laboratory is a student place to practice their psychomotor skills related to nursing interventions. The changes in the nursing curriculum from the curriculum of 2000 to 2015 for the undergraduate level at Nursing Faculty of Padjadjaran University have an impact on the laboratory development in supporting the student to achieve their target study. It is essential to identify nursing students' perceptions on the management of nursing laboratory from various aspects including physical aspects (infrastructure and material), learning processes, and human resources. This study used the descriptive quantitative approach to identify perceptions of nursing students about the nursing laboratory. The sample in this study was 402 students. A questionnaire used in the data collection. The data were analysed using percentage, median and IQR score were measured using the Likert scale. The results of the study found that the Physical and Safety aspects were the highest aspects with median value: 32 and the IQR value of 4. This study is expected to contribute to developing the nursing faculty laboratory as students' need and as an evaluation for the laboratory staffs and lecturers in improving services for students in the laboratory.
\end{abstract}

Keywords: Nursing laboratory, perception, students. 
Sari Ali Astuti: Nursing Students' Perceptions on The Management of Nursing Laboratory

\section{Introduction}

Indonesia has made a significant movement in expanding health services for Indonesian since the 1980s, and this has had an impact on health services facilities, programs, and human resources. The increasing number of health services require health professionals from professional education levels to improve the quality of health services (World Bank, 2012). Nurses are the largest number of health workers in Indonesia, compared to doctors, dentists, and midwives (Lestari, 2014; World Bank, 2012). In December 2016, the number of nurses reached around $30 \%$ of all health workers in Indonesia (Ministry of Health of the Republic of Indonesia, 2017). In line with the demands of globalization, one of which was marked by the launching of the ASEAN Economic Community (MEA) in 2015, Indonesian nurses should have strong competitiveness with nurses from other countries due to the openness of the labor market. Thus, Indonesian nurses should master the competence of professional nurses (Gunawan \& Aungsuroch, 2015; Lestari, 2014).

Sawatzky, Enns, Ashcroft, Davis, and Harder (2009) state that nursing education plays a central role in determining the ability of nurses to carry out nursing actions effectively. Nurses who are educated adequately will provide optimal service for patients. Nursing undergraduate education is held with the aim of producing beginner scientists and professionals who have profiles as care providers, community leaders, educators, managers, and researchers (Faculty of Nursing, Padjadjaran University, 2017). Therefore, nursing education faces the challenge of developing a design and implementing learning activities to facilitate students in improving procedural skills and applying patient safety principles (Ewertsson, Allvin, Holmstrom, \& Blomberg, 2015).

The clinical skills laboratory is an important place where nursing students can practice practical skills through various methods, such as simulations that resemble the actual clinical environment. The simulations can be done at low and medium fidelity levels (eg static mannequins, task trainers, role play, computer games, and standardized patients), or at high fidelity levels with various treatment scenarios developed with computerized models (Ewertsson et al ., 2015). According to the Regulation of the State Minister for Administrative Reform and Bureaucratic Reform [Permenpan] number 03 of 2010 it is stated that 'educational laboratories are academic support units in educational institutions, in the form of closed or open spaces, permanent or mobile, managed systematically for testing, calibration and or production on a limited scale, using equipment and materials based on certain scientific methods, in the context of implementing education, research and community service '(Kemenpan, 2010). While the nursing laboratory is a place that consists of a room or group of rooms equipped with mannequins, anatomical models and equipment similar to hospital units. Apart from the educational aspect, training in the laboratory is also effective for students from ethical-legal aspects in order to reduce errors (errors) that can threaten patient safety (Felix, Faro, \& Dias, 2011).

Aldridge (2017) reveals that for nursing students, the ability to do psychomotor skills properly is very important if you want to become a competent nurse. Through a qualitative review, Aldridge (2017) identified 6 main themes related to the perception of nursing students about learning psychomotor skills, namely (1) the importance of peer existence; (2) practice directly with humans more effectively; (3) the ability and support of teaching staff is very necessary; (4) a conducive skills laboratory environment is very important; (5) patients need student skills; and (6) anxiety always arises during the learning process. Other literature states that educators cannot assess skills in one appearance and hope students will maintain them. Skills must be practiced regularly and given reinforcement. Also, keep in mind that displaying a practical skill, cognitive and affective elements is also important and the process of obtaining skills for each student is not the same (Aldridge, 2017).

Changes in the nursing undergraduate curriculum from the 2000 curriculum to 2015 at the Nursing Faculty of Padjadjaran University were driven by global developments (Faculty of Nursing, Padjadjaran University, 2017), 
Sari Ali Astuti: Nursing Students' Perceptions on The Management of Nursing Laboratory

it gives implications for the development of laboratories to support the achievement of students' learning targets in each subject. In this case, the nursing laboratory is a facilitator for integrating knowledge and skill of student thus bridging the actual practice of the health services (Ewertsson et al., 2015).

\section{Research Method}

This research was a descriptive quantitative study. The research was conducted at the Laboratory of the Faculty of Nursing, Padjadjaran University in August-November 2018. The population in this study was undergraduate students of Faculty of Nursing, Padjadjaran University, year entrance 2017, 2016, and 2015, who had subject with Laboratory skills. The sampling technique in this study used total sampling, the sample of this study was 402 people.

The instrument used in this study was a questionnaire. The questionnaires developed and tested the validity and reliability. The questionnaire assessed three aspects including : physical aspects (infrastructure and security), aspects of the learning process, and aspects of human resources with a total question is 34 items. The analysis of this study used percentage, and median to obtain IQR value from the value measured using the Likert scale including Disagree $(\mathrm{TS})=1$ Less agree $(\mathrm{KS})=2$ Agree $(\mathrm{S})=3$ Strongly agree $(\mathrm{SS})=4$. After the results can determine students' perceptions of the three aspects

\section{Research Results}

Table 1 Characteristic of respondents $(n=402)$

\begin{tabular}{|c|c|c|}
\hline Variable & Frequency (f) & Percentase (\%) \\
\hline \multicolumn{3}{|l|}{ Age (years) } \\
\hline 17 & 1 & 0.2 \\
\hline 18 & 12 & 3 \\
\hline 19 & 132 & 32.8 \\
\hline 20 & 131 & 32.6 \\
\hline 21 & 104 & 25.9 \\
\hline 22 & 22 & 5.5 \\
\hline \multicolumn{3}{|l|}{ Sex } \\
\hline Female & 360 & 89.6 \\
\hline Male & 42 & 10.4 \\
\hline \multicolumn{3}{|l|}{ Year of Study } \\
\hline 2017 & 149 & 37.1 \\
\hline 2016 & 133 & 33.1 \\
\hline 2015 & 120 & 29.9 \\
\hline
\end{tabular}

Table 2 Students' perceptions on the management of nursing laboratory $(n=402)$

\begin{tabular}{lccccc}
\hline \multicolumn{1}{c}{ Variable } & Score & Min & Maks & Median & IQR \\
\hline $\begin{array}{l}\text { Physical and } \\
\text { safety }\end{array}$ & $11-44$ & 22 & 43 & 32 & 4 \\
$\begin{array}{l}\text { Learning } \\
\text { Process }\end{array}$ & $10-40$ & 21 & 40 & 29 & 4 \\
$\begin{array}{l}\text { Human } \\
\text { resources }\end{array}$ & $10-40$ & 21 & 40 & 30 & 3 \\
$\begin{array}{l}\text { Students' } \\
\text { perceptions }\end{array}$ & $31-124$ & 73 & 121 & 91 & 9 \\
\hline
\end{tabular}


Sari Ali Astuti: Nursing Students' Perceptions on The Management of Nursing Laboratory

The results are presented in tables based on the variables. Table 1 present the characteristic of respondents. The table describes that the majority of respondents were 19-20 years old $(n=263)$. Most respondents are women $\mathrm{n}=360(89.6 \%)$. Furthermore, the number of respondents from the 2017 class was larger than the other two classes which are 149 respondents $(37.1 \%)$.

Table 2 shows the results that the median value for Physical and Safety aspects is 32 with an IQR value of 4; the lowest is in the aspect of the learning process of 29 with an IQR value of 4. For Student Perception values obtained a median value of 91 with an IQR value of 9 .

\section{Discussion}

Student nursing interventions skills are very important in the learning process because these interventions would be applied in their work environment. The laboratory as part of study facilities has a very significant role in developing nursing students practice skills. Student perceptions about managing nursing laboratories are needed to improve laboratory services. The results of this study are useful as the basis of information on laboratory development because research on laboratory management based on student perceptions is still limited.

Students' perceptions of laboratory management were known by using an instrument in the form of a questionnaire. Aspects that measured are consist of three aspects: physical aspects (infrastructure and material), aspects of the learning process, and aspects of human resources. The results showed that the Physical and Safety aspects (Table 4.1) became the highest aspect at the median value of 32 with an IQR value of 4 . Human Resource Aspects had a median value of 30 with an IQR value of 3 and the last aspect was the learning process that had the lowest of median value which is 29 and an IQR value of 4 .

The physical and safety aspects examine the views of students on laboratory facilities and infrastructures such as the area, spatial planning, storage of tools and consumables, hazardous waste sites, personal protective equipment, and disposal systems that are related with the learning process or practical needs for students. The physical and safety aspects that have the highest score are personal protective equipment that is always available in the laboratory (eg Handscoon and Masks) which is equal to 3.21 with SD (Standard Deviation) 0.533. In this study, it can be seen that respondents believe that the existence of Personal Protective Equipment in nursing laboratories is always available. This is contrary to the research conducted by Felix et al. (2011) which states that students assess laboratory physical structures as poor or mediocre.

The lowest score of the physical and safety aspects is the availability of practicum equipment at 2.66 with SD 0.644. In this study it can be seen that the availability of practicum equipment in the laboratory is in poor condition, some tools need to be updated and renewed. This is in line with the research conducted by Felix et al. (2011) which states that students assess the laboratory's physical structure was poor.

The learning process is an interaction between 3 main variables: learning environment and student characteristics (presage); student approach to learning (process); and learning outcomes. Briefly, the model explains that personal and situational factors would influence a student to adopt a particular approach in the learning process, so that it may affect learning outcomes. In addition, presage (predictive) factors such as student perceptions (for example about the learning environment) directly affect learning outcomes (Lizzio, Wilson, \& Simons, 2002).

In this aspect the highest median value is before the laboratory practicum, each student has prepared his/her own laboratory clothes/ lab coats as a personal protection tool during the practicum of 3.38 with a value of SD 0.500 . In this case, students have agreed to prepare for personal protective equipment before carrying out practical activities in the laboratory. The lowest value in the aspect of Learning Processes is the practicum activities both inside and outside the laboratory, students are always accompanied by a tutor who has been appointed by the lecturer with median 2.44 and SD 0.694. This shows that most students do not get assistance when 
Sari Ali Astuti: Nursing Students' Perceptions on The Management of Nursing Laboratory

practicing in the laboratory.

Human resources are students' views about laboratory staffs (Educational Laboratory Institutions) regarding services provided, attitudes and behavior, as well as basic tasks and functions of laboratory staffs (PLP). The highest value in this aspect is that PLP responsibilities related to laboratory equipment including cleaning, arranging and stores equipment, facilities, and infrastructure to support practicum. The analysis finds a score median of 3.14 with a value of SD 0.492. In this case, it shows that students agree that the equipment, facilities, and infrastructure supporting the practicum are cleaned, organized, and stored by PLP. The lowest average value in the aspect of human resources is after the practicum finish. Students get advice from PLP to sorting waste (needles, fluids, PPE, and other materials) which are produced at practicum with score 2.71 and SD 0.609. In this case, it shows that not all students are willing to help at sorting out the waste produced during practicum.

The total value of Student Perception about laboratory management has a median value of 91 with an IQR value of 9. It can be seen that students' perceptions of the management of nursing laboratories are considered to be quite good in general although there is still some aspect that had low median and IQR. The perceptions of the year 2015 students were more profound than junior generation students $(2016,2017)$, it may because of they are exposed more to the dynamics of practical activities and the environment in the laboratory than junior students.

\section{Conclusion}

The results of the study on Student Perception of the Nursing Faculty of Padjadjaran University regarding Management of the Nursing Laboratory obtained that the Physical and Safety aspects were the highest aspect of perceptions, and then followed by the human resources aspect and learning process.

The physical and safety aspects that have the highest score are personal protective equipment. In this study, it can be seen that respondents believe that the existence of Personal Protective Equipment in nursing laboratories is always available. The lowest score of the physical and safety aspects is the availability of practicum equipment that always in good condition. It can be seen there is a need to update and renew the laboratory equipment.

Aspects of the learning process the highest median value is before the practicum. The lowest value in the Aspect of Learning Processes is that during the practicum activities both inside and outside the laboratory, students are always accompanied by a tutor. Providing a tutor is very useful to guide the student in the laboratory. The highest value in the aspect of human resources especially the PLP support. Developing PLP capability is important to improve laboratory services.

\section{References}

Aldridge, M. D. (2017). Nursing Students â€TM Perceptions of Learning Psychomotor Skills : A Literature Review. Teaching and Learning in Nursing, 12(1), 21-27. https:// doi.org/10.1016/j.teln.2016.09.002.

Arikunto, S. (2006). Prosedur Penelitian Suatu Pendekatan Praktik (VI). Jakarta: PT.RINEKA CIPTA.

Baillie, L. (2009). Developing practical adult nursing skills (3rd ed.). Hodder Arnold.

Baillie, L., \& Curzio, J. (2009). Students' and facilitators' perceptions of simulation in practice learning. Nurse Education in Practice, 9(5), 297-306. https://doi. org/10.1016/j.nepr.2008.08.007.

Caliskan, N., Ozturk, D., Gocmen, Z., \& Korkut, H. (2012). The effect of periodic training on the clinical application of nursing students â€TM psychomotor skills. Procedia - Social and Behavioral Sciences, 47(8), 786-791. https://doi.org/10.1016/j. sbspro.2012.06.735.

Dempsey, P. A. D. ; A. D. (2002). Riset Keperawatan Buku Ajar \& Latihan. (S. K. Dian Adiningsih, Ed.) (4th ed.). Jakarta: EGC. Retrieved from https://books.google. 
Sari Ali Astuti: Nursing Students' Perceptions on The Management of Nursing Laboratory

co.id/books?id=k9MdoF0VflgC\&pg=PA26 $9 \& \mathrm{dq}=$ uji + validitas + riset + keperawatan $\&$ hl $=$ en $\&$ sa $=$ X\&ved $=0$ ahUKEwj2q7y79aHZAhV HOo8KHZ9qA60Q6AEINTAC\#v=onepage $\& \mathrm{q}=$ uji validity reset keperawatan $\& \mathrm{f}=$ false.

Ewertsson, M., Allvin, R., Holmstrom, I. K., \& Blomberg, K. (2015). Nurse Education in Practice Walking the bridge : Nursing students â€TM learning in clinical skill laboratories. Nurse Education in Practice, 15, 277-283. https://doi.org/10.1016/j.nepr.2015.03.006.

Fakultas Keperawatan Universitas Padjadjaran. (2017). Pedoman Program Studi Pendidikan Sarjana Keperawatan.

Felix, C. C. P., Faro, A. C. M. e, \& Dias, C. da R. F. (2011). Nursing students â€TM perception of the Nursing Laboratory as a teaching strategy. Revista Da Escola de Enfermagem Da USP, 45(1), 238-244.

Gold, I. (2001). Perception: Philosophical Aspects. In International Encyclopedia of the Social \& Behavioral Sciences (pp. 1120911215). Elsevier. https://doi.org/10.1016/B008-043076-7/00993-1.

Gunawan, J., \& Aungsuroch, Y. (2015). Indonesia health care system and Asean economic community. International Journal of Research in Medical Sciences, 33(77), 1571-1577. https://doi.org/10.18203/23206012.ijrms20150231.

Handini, F. (2013). Persepsi mahasiswa Fakultas Ilmu Keperawatan Universitas Padjadjaran terhadap perilaku caring pembimbing praktik dalam pembelajaran praktikum di laboratorium. Universitas Padjadjaran.

Haraldseid, C., Friberg, F., \& Aase, K. (2015). Nurse Education Today Nursing students â€TM perceptions of factors in fl uencing their learning environment in a clinical skills laboratory: A qualitative study. Nurse Education Today, 35(9), e1-e6. https://doi. org/10.1016/j.nedt.2015.03.015.

Henderson, A., Cooke, M., Creedy, D. K., \& Walker, R. (2012). Nursing students' perceptions of learning in practice environments: A review. Nurse Education Today, 32(3), 299-302. https://doi. org/10.1016/j.nedt.2011.03.010.

Houghton, C. E., Casey, D., Shaw, D., \& Murphy, K. (2012). Staff and students' perceptions and experiences of teaching and assessment in Clinical Skills Laboratories: Interview findings from a multiple case study. Nurse Education Today, 32(6), e29-e34. https://doi.org/10.1016/j.nedt.2011.10.005.

Kementrian Kesehatan Republik Indonesia. (2017). Situasi Tenaga Keperawatan Indonesia. https://doi.org/http://www. depkes.go.id/resources/download/pusdatin/ infodatin/infodatin \%20perawat\%202017. pdf.

Lestari, T. R. P. (2014). Pendidikan keperawatan: upaya menghasilkan tenaga perawat berkualitas. Aspirasi, 5(1), 1-10.

Lizzio, A., Wilson, K., \& Simons, R. (2002). University students' perceptions of the learning environment and academic outcomes: Implications for theory and practice. Studies in Higher Education, 27(1), 27-52. https:// doi.org/10.1080/03075070120099359.

Louis Jolyon West, William Epstein, \& William N. Dember. (2018). Perception. In Encyclopedia Britannica.

Menteri Pendayagunaan Aparatur Negara dan Reformasi Birokrasi Republik Indonesia. (2010). Peraturan Menteri Negara Pendayagunaan Aparatur Negara dan Reformasi Birokrasi Nomor 03 Tahun 2010 tentang Jabatan Fungsional Pranata Laboratorium Pendidikan dan Angka Kreditnya, Pub. L, 3.

Puspita,A.P.W.(2012). Faktor-faktorinternal yang berkontribusi terhadap kedisiplinan mahasiswa program A dalam proses pembelajaran praktikum (skill lab activity) Fakultas Ilmu Keperawatan Universitas Padjadjaran. Univesitas Padjadjaran.

Sawatzky, J. A. V., Enns, C. L., Ashcroft, T. J., Davis, P. L., \& Harder, B. N. (2009). 
Sari Ali Astuti: Nursing Students' Perceptions on The Management of Nursing Laboratory

Teaching Excellence in Nursing Education: $A$ Caring Framework. Journal of Professional Nursing, 25(5), 260-266. https://doi. org/10.1016/j.profnurs.2009.01.017.

The World Bank. (2012). Indonesia: Health Professional Education Quality Project.
Wong, W. F., \& Leong, C. S. U. (2017). Macao nursing students â€TM perceptions about their nursing skill laboratory examination : a qualitative approach, 7(1), 28-33. https:// doi.org/10.5923/j.nursing.20170701.03. 